\title{
ECONOMIC ASSESSMENT OF THE PERFORMANCE OF PRIVATE SECTOR MARKETING OF FERTILIZER IN DELTA STATE - NIGERIA
}

\author{
F.O. ACHOJA, S.O. EBEWORE AND E.C. NWAGBO \\ (Received 13, December 2006; Revision Accepted 14, September 2009)
}

\begin{abstract}
This paper critically attempts to assess the performance of the private sector participants in the marketing of fertilizer in Delta State - Nigeria. A total of 100 respondent fertilizer marketers were randomly selected from four Local Government Areas and studied under the deregulated fertilizer marketing arrangements in 1999. Primary data used for the study were collected with structured questionnaire and analyzed using descriptive statistics of the conventional parameters for assessing market performance and student t-test. The results that the performance of fertilizer marketers was rated 'fair" based on the opinion of the public and the values of major market performance indices viz: marketing margin $(36.04 \%)$ and $(28.7 \%)$ of total revenue, marketing cost $8.75 \%$ and $5.46 \%)$ of total cost, net return $(29.9 \%$ and $24.6 \%)$ of total revenue, market, efficiency value (1.4 and 1.3$)$, at wholesales and retail level respectively. The performance of the private marketers was mainly constrained by inadequate finance, high procurement cost of fertilizer at source, market access condition and poor market information systems. The paper thus recommended that high performance of private sector marketing of fertilizer would require improved market infrastructures and effective information system as policy instruments.
\end{abstract}

KEYWORDS: Economic assessment1 performance, private sector, deregulated fertilizer marketing.

\section{INTRODUCTION}

The sustainability of the crop sub-sector of the Nigerian economy would depend to a large extent on the quantity and quality of inputs such as, inorganic fertilizer that farmers demand and utilize per unity area. As the gains inherent in the use of fertilizer become manifest, the input enjoyed a corresponding degree of awareness and utilization, Thus fertilizer demand of above 1.0 million metric tones was projected in 1993 (Ogunfowora, 1993). But such projection was highly constrained by the bottlenecks and shortfall in the government marketing/distribution operation for fertilizer.

According to Dixie (1989), Marketing is considered as the series of services involved in moving a product from the point of production to the point of consumption or utilization. Thus fertilizer marketing can be conceptualized as all the business activities which direct the downward flow of fertilizer from the producers through the intermediaries to the farmers for utilization.

Harriss (1 993), conceptualized market performance as:

"how well the marketing system performs the business role

that is expected of it by the market participants (buyers and sellers)

and the entire society."

Market performance can be assessed by taking note of some common concerns expressed b the market participants (buyers and sellers) about the market indices; such as exploitative pricing behaviour, product out of-stock, slack filling of containers, high marketing an indication of market performance. The performance of the regularized distribution/marketing arrangement for fertilizer in some parts of Nigeria such as Delta State, was defective at best.

The option of private sector participation in fertilizer marketing was considered and adopted in Nigeria between 1997 and 1999 as a policy strategy for satisfying the increasing demand for the product. A private enterprise system is on economic system

characterized by private production and exchange of goods and services and of resources (Leftwich, 1979). This was considered necessary because the private sector participants could he more efficient in satisfying fertilizer demand of the farmers, since they are known to carry out effective marketing functions without depending on government assistance (Timmer et al, 1993). A structure of private marketing enterprise has important advantage of conformity and competition. Competitive fertilizer marketing with free pricing is likely to promote economic pattern of farm resource at location (Abbott, I 093). In the free enterprise system, marketing is guided by profit motive. High profits for intermediaries has been identified as one of the indices of an inefficient marketing system. The existence of highly performing fertilizer marketing system is thus an inducement for sustainable agricultural production in Nigeria.

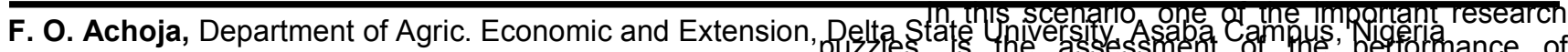
S. O. Ebewore, Department of Agric. Economic and Extensio E. C. Nwagbo, Department of Agricultural Economics, University of Nigerla Nsukka, Niger market-orlented ramework cost, as well as marketers insensitivity towards consumers' welfare. An evaluation of market retail price spreads (i.e marketing margin) and parity prices. The profit range accruable to market participants also gives such as profit range, marketing cost, marketing efficiency, marketing margin, volume traded and associated consumers complaints. This is a view to evaluating how efficiently the private sector was able to 
fill the gap created by the exit of the government parastatal from fertilizer marketing. The objectives of the investigation were to assess the performance of private sector in fertilizer marketing and examine the socioeconomic constraints that affected the performance of deregulated fertilizer marketing in Delta State.

\section{Research Methodology}

The primary data used for this investigation emanated from the 1999 field survey of private fertilizer marketers. A sample of 100 respondent fertilizer marketers was composed using a random sampling technique. Respondents were selected from four Local Government Area in Delta State, Nigeria. These included Ethiope-East Ughelli-North. Uvwie and Okpe L.G.As. Structured and validated questionnaire was the main instrument used for the collection of primary data for the study.

\section{Data Analysis Technique}

Primary data collected were analyzed using appropriate statistical tools such as mean, mode, range, standard deviation, percentage and student-t-test. To determine marketing margin, data were collected on the cost price of fertilizer per $50 \mathrm{~kg}$ bag at source and the selling price of fertilizer per $50 \mathrm{~kg}$ bag. Information was also collected on the cost of transportation, labour, loading, off-loading, storage, spoilage and payment for other marketing services. These data were considered useful in determining the marketing cost of fertilizer. The Net Return accruable to all types of dealer was determined by adopting the Profit Model of Utomakili and Amuda (1991) as shown below:

NRTM = Q (UMM - UMC)

Where:

$\begin{array}{lll}\text { NTRM } & = & \text { Net return to marketers }(\mathrm{N}) \\ \mathrm{Q} & = & \begin{array}{l}\text { Quantity of fertilizer traded in } \\ (\mathrm{kg})\end{array} \\ \text { UMM } & = & \text { Unity marketing margin of } \\ \text { UMC } & = & \text { Unitilizer }(\mathrm{N})\end{array}$

(N)
The straight line method of depreciation was used for the fixed assets of the business. And the market interest rate at the time of the study, which was used for estimating the cost of financial capital used in one year, was $20 \%$

\section{Results and Discussion}

The liberalized marketing arrangement for Nigeria economy provides an appropriate framework for a critical analysis of fertilizer marketing in Delta State of N.igeria. Within this framework the results of the study covers the following: Fertilizer Marketing System, and (market structure); Fertilizer market performance, using volume of operation of dealers, net profit range of dealer and marketing cost, marketing margin and market efficiency ration as indices of fertilizer market performance.

\section{Fertilizer Marketing Structure}

The structure of the fertilizer market in Delta State changed since market- orientation was extended to fertilizer sector. Hence fertilizer marketing in the area transited from a monopolistic system to a perfect competition arrangement. One of the noteworthy features of fertilizer market structure in the study area was its pricing mechanism. In which, fertilizer prices were subject to and directed by the market forces of demand and supply. Thus fertilizer marketers and consumers were price takers.

Relatively uniform prices were charged by every dealer in all fertilizer demand centres. Fertilizer consumers (farmers) had information on the prices of the various packages (bags and baskets) of fertilizer being sold in $10 \mathrm{~kg}$ sachets and baskets. This may be due to low income, small farm size, portability etc.

Though the deregulated fertilizer market environment allowed free entry and exit of private dealers, the market structure in the study areas was still dominated by few independent wholesale dealers $(30 \%)$ and more retailers $(70 \%)$ that were scattered in the rural areas as shown in table 1.1 below:

Table 1: Percentage Concentration of Fertilizer Market Dealers in the Study Area

\begin{tabular}{lllll}
\hline S/N & L.G.A & \% Wholesaler & \% Retailer & Total \\
\hline 1 & Ethiope East & 10 & 25 & 35 \\
2 & Okpe & 5 & 15 & 20 \\
3 & Ughelli-North & 10 & 20 & 30 \\
4 & Uvwie & 5 & 10 & 15 \\
& Total & $\mathbf{3 0}$ & $\mathbf{7 0}$ & $\mathbf{1 0 0}$ \\
\hline
\end{tabular}

(Source: 1999 Field Data)

This result shows that the fertilize $5 r$ marketing in a deregulated economy as progressive hut very gradual. The small scale farmers enjoyed some benefits in the deregulated market in Delta State. Some of such benefits include:

(1) Fertilizer consumers in the enjoyed the advantage of access to alternative retail outlets

(2) $30 \%$ of the independent dealers sometimes supplied fertilizers on credit in addition to
(4)

members. They operated favourably and efficiently as they were occasionally assisted technically by government extension officers. Hoarding of fertilizer was minimized. This was indicated by the average size of stock per wholesale stock (237.17 bags), and 8.6 bags per retail store.

These notwithstanding, the fertilizer marketing system in Delta State under private sector arrangement

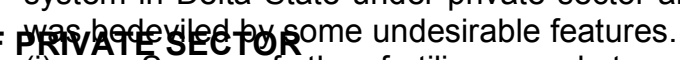


and thus there were cases of occasional out-ofstock COIT1 plaint S.

(ii) Secondly, very few of the dealers practised market integration i.e (sale of complementary agro-chemicals and improved seeds) as a way of against fertilizer market risk (Failure).

(iii) Furthermore, the area is expected to witness a continuous expansion of demand for fertilizer. And as fertilizer trade accordingly expanded, more working capital was needed to finance the increasing tonnage on the part of the marketers.

Performance of Private Sector Marketing of Fertilizer on the basis of Marketing Margin and Marketing Cost

The result of the analysis of fertilizer market performance in the study area on the basis of marketing and marketing cost is presented in table below.

Table 2: Descriptive Statistics of Revenue at the Retail and Wholesale level in Study Area under a private sector arrangement

\begin{tabular}{llll}
\hline S/N & Revenue & Wholesale & Retail \\
\hline & Average Quantity of fertilizer traded (50kg bags) & 237 & 9.0 \\
ii. & Average Total Revenue (N) & 333,725 & $16,964.3$ \\
iii & Average Total Marketing Margin (N) & $120,275(29.9 \%)$ & $4,864.29(28.75)$ \\
iv & Average Net Return to Marketers & $99,700(29.9)$ & $5,165.43(24.6 \%)$ \\
v. & Percentage Net Return to Marketers & $42.6 \%$ & $32.5 \%$ \\
\hline
\end{tabular}

(Source: 1999 Field Data)

Note: (a) The figures in parenthesis in rows II and II are the corresponding percentages of total cost.

(b) The figures in parenthesis in row IV, VI and VII are the corresponding percentages of average total revenue.

The result shows that about $36 \%$ of the total revenue was accountable to the total marketing margin at the wholesale level. While at the retail end, average total marketing margin was $29 \%$ of the average total revenue. This relatively low marketing margin indicates a fair performance of fertilizer market in a deregulated system. This has implication for improved utilization of fertilizer by farmers.

This finding agrees with the earlier observation of Zuvekas (1977) when he asserted that a low marketing margin would result in more gains to input users. Also Ahmd and Rustagi (1993) had earlier noted that marketing margin is often lower $n$ a deregulated system than in an institutionalization marketing system.

Table 3: Descriptive Statistics of mean Marketing Cost at Retail and Wholesale Levels

\begin{tabular}{llll}
\hline S/N & Cost (N) & Wholesale & Retail \\
\hline i. & Marketing & $20,515(8.78 \%)$ & $698.86(5.46 \%)$ \\
ii. & Cost of fertilizer & $213,450(91.21 \%)$ & $12,100(94.45 \%)$ \\
iii. & Total cost & $234,025(100 \%)$ & $12,798(100 \%)$ \\
\hline
\end{tabular}

(Source: 1999 Field Data)

Furthermore, a component analysis of data revealed the performance of fertilizer market on the basis of marketing cost. Approximately $9 \%$ of the average total cost account for marketing cost; while $91 \%$ accounted for cost of fertilizer stocks.

The absence of subsidy on fertilizer could be responsible for the high cost of fertilizer stock in 1999. Also the deplorable state of the rural roads could have influenced the high marketing cost in the study area. This further implies that the poor market access condition of the area is an important socio-economic factor that could adversely affect the performance of fertilizer marketing in the study area.

\section{Fertilizer Market Efficiency}

Fertilizer marketing efficiency is the ration of the value marketing outputs (total revenue) obtained from fertilizer marketing activity to the value of marketing

inputs (total cost) necessary to market the product. The higher the value of marketing output in per Naira worth of marketing resource input, the greater is the efficiency of the market.
The results of this study indicated that marketing efficiency for fertilizer wholesalers was 1.45 , while that of the fertilizer retailers was 1.30. Since the marketing

60

efficiency ratio (ME.) positive and greater than one, one can infer that private sector marketing of fertilizer demonstrated relatively high performance in the study area. This means the resources were efficiently allocated and that resource productivity was equally high. This agrees with the assertion of Downey and Erickson (1981) that marketing efficiency is often used in evaluating the performance of the marketing process. Hence the two dimensions of marketing efficiency (Operational and pricing efficiency) measure the performance of marketing services and marketing cost, respectively.

\section{Performance of Fertilizer Marketing on the Basis of Profit Range}

The net return to all the respondent marketers (NRTM) of the fertilizer in the study area is presented in table 3 below. Using the value of the difference between total revenue $(\mathrm{Q}(\mathrm{UMM})$ or $\mathrm{TR})$ and total cost $\mathrm{Q}$ (UMC) or (TC), NRTM was determined. 
The mean net return to wholesalers was N212200. The minimum net return obtained by wholesalers was $\$ 24,000$; while the maximum was $\mathrm{N} 43$ 5,000 per annum. Thus the profit range was determined to be 4411,000 .

However, fertilizer retailers in the study area had a mean net return of $N 4,164.71$. The minimum and the maximum NRTM obtained were $\$ 2,500$ and $\$ 9,900$ respectively. Thus the profit range at the retail level was determined to be $\$ 7400$. About $85 \%$ and $57 \%$ obtained the net return that were below the mean net profit values at wholesale and retail levels respectively.

These results showed that more dealers enjoyed lower net returns in the study area. This implies that the seasonal profits accruable to private fertilizer marketers under the liberalization arrangement was generally low. Furthermore,' on the average, $42.6 \%$ and $32.5 \%$ were the percentage gain at the wholesale and retail levels respectively as shown in table 2.0 above. These findings imply that every $\mathrm{Ni} 00$ invested on fertilizer marketing at wholesale and retail levels could yield a gain of approximately N43 and N33 to the investors, all other things being equal.

That not withstanding, to shows that the percentage gains reported above is significantly different from zero, the following research hypothesis was formulated and tested.

\section{Research Hypothesis}

Ho: There is no significant difference in the profit range of all private fertilizer marketers in the study area. i.e $\quad \Pi_{\text {Wholesaler }}=\Pi_{\text {Retailer }}$

Using a one tail test at $5 \%$ level of significance and at $n_{1}+n_{2}-2 d f$, the calculated value of student $t$-test $=$ 2.45. This is greater than the table value of $t=1.7342$.

i.e $t$. cal $=2.45>t_{0.05}=1.7341$.

\begin{tabular}{lllllllll}
\hline & $\mathbf{X}$ & SD & $\mathbf{n}$ & $\mathbf{n}_{\mathbf{2}}$ & $\mathbf{d f}$ & t.cal. & t.tab & Remark \\
\hline Wholesaler $\left(\boldsymbol{\Pi}_{\mathbf{1}}\right)$ & 212200 & 206996.06 & 30 & 14 & 98 & 2.45 & 1.96 & $\begin{array}{l}\text { Reject Ho and } \\
\text { Accept Hi }\end{array}$ \\
\hline Retailer $\left(\boldsymbol{\Pi}_{\mathbf{2}}\right)$ & 4164.71 & 2152.89 & 70 & & & & & \\
\hline
\end{tabular}

With this result, we reject the null hypothesis and accept the alternative hypothesis which states that there is significant difference in the profit range of fertilizer marketers in a deregulated system in the study. The inference is that the private sector marketing of fertilizer in the study area within the period of the study (1999), exhibited profitability among all the participants and permitted very little or no room for the exploitation of fertilizer users. These are indications of good market performance.

\section{Socio-Economic Constraints to Private Sector Marketing of Fertilizer}

The results of socio-economic constraints affecting private sector marketing of fertilizer in the study area is presented in table below

Table 5: Percentage Distribution of Socio-Economic Constrains to Private Sector Marketing of Fertilizer in the Study Area

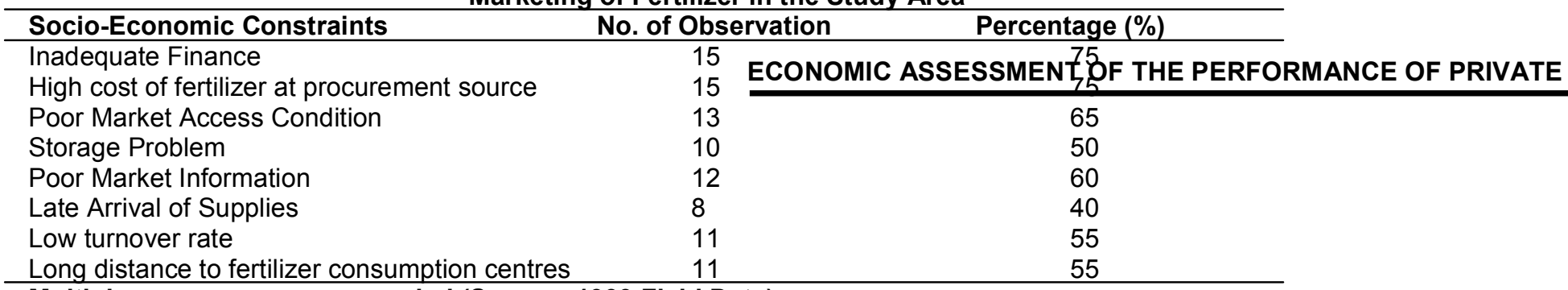

Multiple responses were recorded (Source: 1999 Field Data)

Respondents indicate that the most prevalent socio-economic constraints that effected fertilizer marketing in the study area within the period of the study, were inadequate financer $(75 \%)$ and high cost of fertilizer at source (75\%). This implies that fertilizer marketing in the study area was capital intensive. This further point to the fact that a high proportion of fund invested in fertilizer marketing goes to the cost of procuring fertilizer stock. This constraint is enough to discourage private dealers with poor financial resources. Operating capitals were needed all through the fertilizer marketing system; right from the procurement, transportation and distribution through the marketing channel to the farmer. Abbott (1993), had earlier observed that in many developing countries, the funds of local traders of fertilizer limited such that to start fertilizer marketing, they would need external financing.

Respondent fertilizer marketers also reported other socio-economic constraints that affect private sector marketing of fertilizer. They include: poor market access condition (65\%); poor market information (60\%), low turnover rate $(50 \%)$, long distance to fertilizer consumption centres (50\%). storage problem (50\%) and late arrival of fertilizer supplies (40\%).

Policy Recommendation Domain

On the basis of the findings of this study the following policy recommendations were proffered.

(1) Extension officers should be made to play advisory role in the open market arrangement for fertilizer marketing so that the full 
complementary ser ices attached to fertilizer package could be enjoyed by the users (farmers).

(2)

There should be the establishment of effective fertilizer market information systems. This will help to assist fertilizer producers, dealers and users in taking full advantage of fertilizer market opportunities.

(3) More fertilizer plants should be established in the southern part of Nigeria. Also the capacity of the existing NAFCON should be expanded to enable it, at least contribute substantially in meeting the huge demand for the product in Nigeria, instead of waiting for any slightest opportunity to import fertilizer by dealers.

(4)

Considerable efforts should be expended on adequate provision, improvement and maintenance of market infrastructures such as urban-rural transportation networks. This will enhance easy flow of fertilizers and reduction in transportation cost as a component of marketing cost in the study area.

(5) Since fertilizer marketing is capital intensive, government should convert the existing fertilizer subsidy to fertilizer loan scheme that would be accessible to fertilizer marketers.

\section{Conclusion}

This study has demonstrated that indigenous private sector marketing arrangements are often not as exploitative as abinitio supposed; and that with a conductive institutional and improved infrastructural environment (market access condition) in which they operate, they have the tendency to be efficient. By focusing on market efficiency, this study has highlighted important dimensions of fertilizer market performance such as fertilizer product flows, fair pricing, price stability and price uniformity in the marketing system. Government should reconsider the policy option of shifting the responsibility of fertilizer marketing/distribution to the private entrepreneurs. They are efficient in playing this role better than the government parastatals.

\section{REFERENCES}

Abbott, J. C., 1993. "Financing Fertilizer Distribution Network" cited in Abbott, J.C. (ed.) Agricultural
Selected Reading. UK: CTA and C.A.B. International Publications.

Ahmed, R. and N. Rustagi., 1993. "Agricultural Marketing and Price Incentives: A Comparative Studies of African and Asian Counties" cited in Abbott, J.C. (ed.) Agricultural and Food Marketing in Development Countries: Selected Reading; UK: CTA and C.A.B. International Publications.

Dixie, C., 1989. "Horticultural Marketing”. A Resources and Training Manual for Extension Officers. F.A.O. Agricultural Services Bulletin, Rome: FAO of United Nations.

Downey. D.W. and S. P. Erickson., 1987. Agribusiness Management $\left(2^{\text {nd }}\right.$ ed.) New York, USA: McGraw Hill hit.

Harriss, B., 1993 "Measuring Market Performance" In Abbott, J.C. (ed.) Agricultural and Food Marketing in Developing Countries: Selected Readings: UK: CTA and C.A.B. International Publication.

Leftwich, R. H., 1979. The Price System and Resource Allocation $\left(7^{\text {th }}\right.$ ed.) Illionis: The I)Iden Press P. 477

Ogunfowora, O., 1987. "Fertilizer Policy and Programmes in Nigeria". Proceedings of the National Fertilizer Seminar $\left(18^{\text {th }}-30^{\text {th }}\right.$ October, 1987) Port-Harcourt; FM A WARD.

Timmer, C. P., Falcon and S. R. Pearson., 1993. "The Non-answer to Food Productions" citied in Abbott, J.C. (ed.). Agricultural and Food Marketing in Developing Countries: Selected Readings; UK: CTA and C.A.B. International Publications.

Utomakili, A. and C. Amuda., 1991. "An Assessment of Return to Management in Goat Marketing in Ondo State", cited in Abraka Journal of Agricultural Vol. Pp. 70-73.

Zuvekas, C., 1977. "A Survey of Crops and Livestock Marketing in Bolivia" USAID Working Document

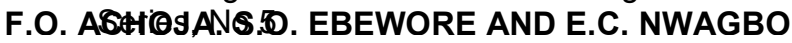

\section{APPENDIX}

Table 6: Net Profit to Fertilizer Marketing (Wholesalers)

\begin{tabular}{ll}
\hline S/No. (Respondents) & NRTM (ח) (N) \\
\hline 1 & 435,000 \\
2 & 450,000 \\
3 & 300,000 \\
4 & 37,000 \\
5 & 27,000 \\
6 & 24,000 \\
\hline$\sum X_{1}$ & $1,273,200$ \\
$\mathrm{X}_{1}$ & 212,200 \\
$\mathrm{SD}_{1}$ & $206,996.04$ \\
$\mathrm{~N}_{1}$ & 6
\end{tabular}


Table 7: Net Profit to Fertilizer Marketing (Retailers)

\begin{tabular}{ll}
\hline S/No. (Respondents) & NRTM (ח) (N) \\
\hline 1 & 9940 \\
2 & 2500 \\
3 & 2650 \\
4 & 5360 \\
5 & 2630 \\
6 & 4256 \\
7 & 5300 \\
8 & 6384 \\
9 & 2600 \\
10 & 3186 \\
11 & 2720 \\
12 & 2700 \\
13 & 2680 \\
14 & 5350 \\
\hline$\sum \mathrm{X}_{2}$ & 58306 \\
$\mathrm{X}_{2}$ & 4164.71 \\
$\mathrm{SD}_{1}$ & 2152.89 \\
$\mathrm{n}_{1}$ & 14 \\
\hline
\end{tabular}


